\title{
Human Resources on Increasing Teacher Performance in Islamic Education Institution
}

\author{
Aminatul Zahroh ${ }^{1}$, Khurotin Anggraeni' ${ }^{2}$ Muhamad Faizul H ${ }^{3}$, H. Karim ${ }^{4}$ \\ 1,2IAI Pangeran Diponegoro Nganjuk, East Java Indonesia \\ ${ }^{3}$ Nahdatul Ulama University Purwakerto, Central Java Indonesia \\ ${ }^{4}$ MTs Negeri Jombang 7 Jombang, East Java Indonesia \\ *qu10anggra@gmail.com (Corresponding Author)
}

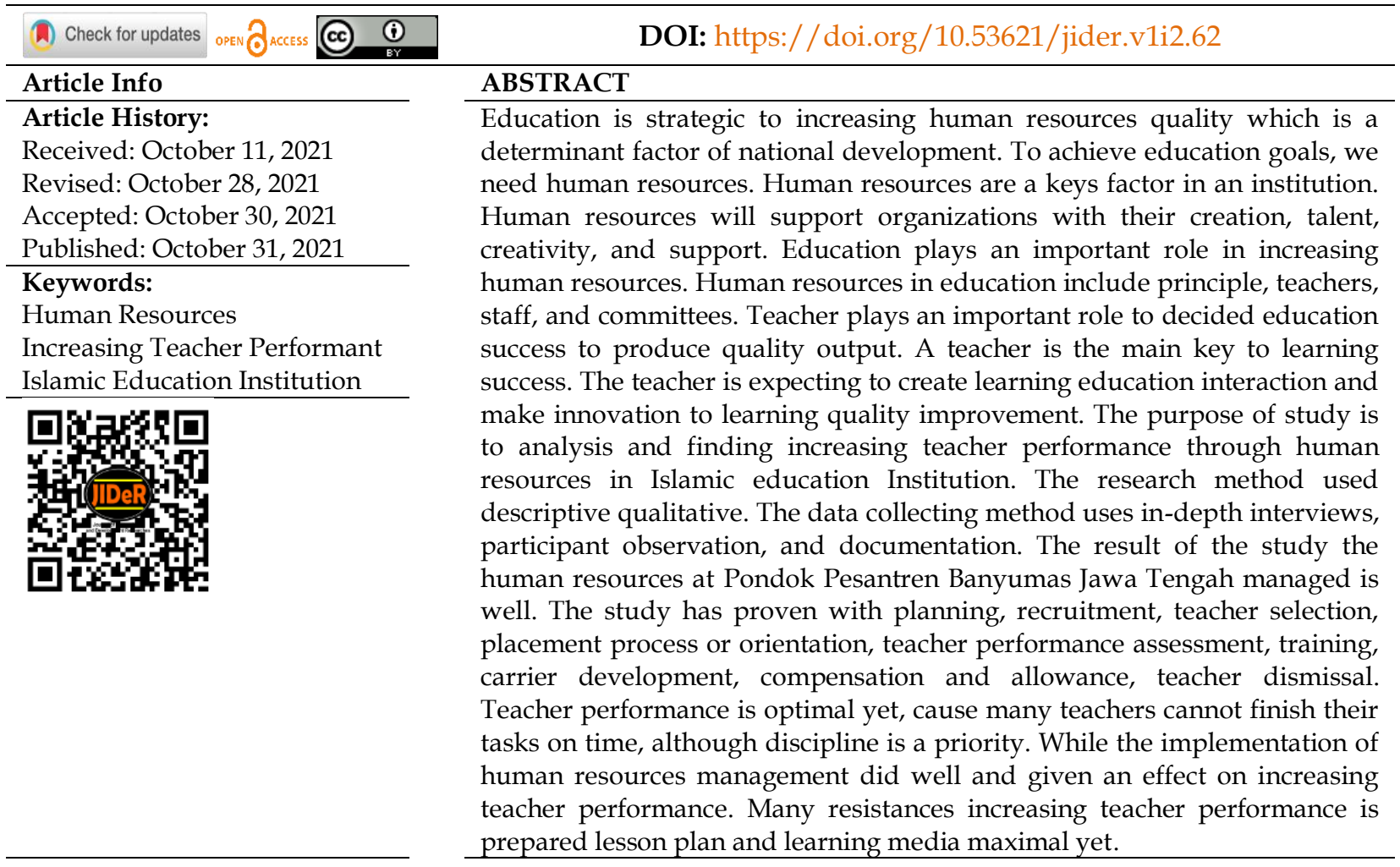

\section{INTRODUCTION}

Education is a strategy to increasing human resources that determinant factor of national development (Koiron Rosyadi, 2014). Education is a conscious effort to prepare students through coaching activity, teaching, and training for a future role means minimize other component contributions. A teacher is one of the essential factors that determine learner quality. Education is strategic to increasing human resources quality (Muhaimin, 2016).

Human resources are human who works in an organization namely personal, workforce, worker, or staff. Human resources mean the human potential used to drive an organization to present its existence (Syafruddin Nurdin, 2013). Human resources in education are all the determinants and implementation of the activities, policies, and programs which is aim to get teacher, development, and maintenance as an effort to increasing organization effectivity, ethic and social can responsibility (Nanang Fattah, 2015).

Human resources are the main problem faced by education institutions. Human resources management plays an important to increase education institutions' effectiveness and efficiency (Abdurrahmat Fathoni, 2013). Many resources are needed by an education institution, such as human, infrastructure, budget, technology, and information. A more Important resource in education is human resources. Human is an important resource for educational institution 
development. As the main factor in education, Human resources is always a development object. Human resources will support the organization with its creation, talent, creativity, and support. Perfect technology and economic did not accompany by human resources will be difficult to achieve the educational institution's goal (Muhaimin, 2016). Human resources are need development, competent human resources to become survive, and successful educational institutions. It is present that human resources as kays factors in education institution success. Therefore, human resources are needed to manage well and empowerment to the development education institution (Syafruddin Nurdin, 2013).

Human resources need to manage and develop is teachers. The teacher is determining factor of education institution success (Ibrahim Bafadal, 2012). A teacher is a professional staff with their woks quality means a quality performance will present teacher quality professional. Another side, a performer with a low standard is a present unsuccessful teacher. Therefore, teacher professional development is coaching and pay attention as a commitment to the improvement of education types to achieve the education quality. Quality of teacher ability will affect lower education quality (Moh. Uzer Usman, 2012).

Human resources management has a great influence and main key to increasing education quality. The existence of human resources in education is very important. The problem of human resources management in education institutions is teacher placement that is unsuitable for their job, minimum salary, missing promotion, training, and teacher development. Remember that the importance of human resources, the teacher performant is needed continuous (Sofyandi Herman, 2014).

Teacher performance is a real behavior as work achievement present by the teacher to the implemented education process in school or education institution. Good teacher performance is make with self-awareness of teacher and support from leadership to understanding the responsibility of teaching and present their professionalism (Syafruddin Nurdin, 2013). A keys success of learning is in the teacher's hand which, is an effort to increasing education quality through teacher performance. It is not a simple problem but needs special pay attention with multidimensional to involve all elements. Therefore, to increasing education quality, expertise creates innovation to improve teacher performance quality.

However, Indonesia education is an expected yet, education institution able to produce human resources quality yet. It is seen from the expensive of educational cost, the majority of Indonesian society is middle and lower economic community. High education cost is not accompanied by society income. It has become a factor backwardness education of Indonesia. Different conditions, development knowledge, and technology can influence teacher performance. In this case, teacher quality can see from their performance. To measure teacher performance is need evaluation, competency, and discipline to increasing teacher quality.

According to Siagian, Performance is influenced by many factors are work environment, organization culture, leadership, and work motivation, discipline, salary, work satisfaction, and other factors (Siagian, 2013). Performance is resulted by their ability and discipline has by someone. If someone has high ability but they did not have discipline, they cannot produce a good performance, vice versa. Teaching ability is something important. Ability teacher on teaching batter will be a high achievement. Without teaching, the ability will be difficult to achieve teacher competency maximally. Similarly with Marsana and Handayani said that high competency is deciding performance level. Decided competency is based on the selection process, planning, performance evaluation, and human resources development (Marsana and Handayani, 2012).

To know the teacher's performance is through their competency and discipline. Discipline is influencing on teacher performance. Without discipline, a teacher will not work suitably with the organization expected. Generally, a teacher can achieve the work expected if they have good discipline. Good discipline is present their responsibility on their task. It pushes work motivation, work spirit, and achieve educational institution goals. Therefore, each leader of an institution is always given support to the teacher to discipline to achieve their success and as 
nation generation. Effective leadership is managing a teacher to have a responsibility and good discipline.

Performance is related to discipline. Good discipline will high achievement and high-level discipline, it will high work achievement. Without discipline, educational institutions can't run optimally (Malayu S.P. Hasibuan, 2012). Teacher performant is a perform done by the teachers to running their task as an educator. Teacher quality performance is decided on the quality of education result. A teacher is one always interacts with their student in the education process in the institution.

This study takes a location at Pondok Pesantren Banyumas East Java. Based on the observation result on February 15th 2021 is present that human resources on increasing teacher performance in Islamic educational institutions to play important (Observation, February 15 $5^{\text {th }}, 2021$ 09.30 AM). Pondok Pesanten Banyumas is pondok pesantren and school want all the teacher have good performant. The development of Pondok Pesanten Banyumas Jawa Tengah is decided by human resources quality especially performant. Performace is the base influence and contribution on Islamic education institutions and also the result of service to society, so need reliable human resources to increase teacher performant to achieve Islamic education institution goal. Islamic education institutions must know performant targets in other that human resources can increasing teacher performance and running well. A teacher said that for high performance. If they can achieve their task and realized well even exceed from decided by the Islamic educational institution.

Based on pre-field, the researcher is done introduction of interview and observation to know teacher performance. The result of interview with Chief Pondok Pesanten Banyumas Jawa Tengah is teacher performant known optimally yet. Because many teachers can finish their task on time, another hand is lack responsibility on their task which is influence teaching quality. And many teachers are always late and absent that a sign of low performance of work quality dimension (Interview, February 17th,2021 11.30 AM).Pondok Pesantren Banyumas Jawa Tengah always tries to increase teacher performance to achieve human resources quality and professionalism. Many efforts did by Islamic Institution to improve teacher performance includes giving training to increasing teacher performance.

Pre- field known many dominant factors that influence teacher performance are competency and discipline as dominant factors. According to chief Pondok Pesantren Banyumas Jawa Tengah, many teachers can adapt yet with their performance when they are teaching, especially new teachers. While discipline, A principle said that discipline level optimal yet (Interview, February 17th,2021 11.35 AM). Many teachers are absent without clear reasons, this condition will not achieve the goal (Interview, February 19th,2021 10.30 AM). Based on the pre-field, the researcher is interested to study this problem with the question of how is increasing teacher performance through human resources in Islamic education Institution? The purpose of the study is to analyze and find increasing teacher performance through human resources in an Islamic educational institution.

According to Sutrisno, high discipline will increase workforce performance to speed achieve organization goal, while low discipline will decrease workforce performant, it makes an obstacle to achieve organization goal (Sutrisno, 2011). Similar to a previous study by Tutik Yuliani discipline is influences by teacher performance at SMPN Balikpapan. Teacher discipline means a teacher is always come and go home on time, doing a task well, comply with organization rules and social norms. Discipline is a mirror of high responsibility a teacher on their task. It pushes the passion of work, work spirit, and support to achieve organizational goals. Discipline is an important effort to increasing Islamic educational institutions. In another world, low discipline can damage education institutions (Tutik Yuliani, 2018). Discipline is an action to comply with the rules. If this action is done correctly and continuously, it will become a habitual action on instilled teacher behavior to help achieve organizational goals.

Based on the display above can conclude that teacher performance is playing an important to increasing education quality. Teacher mistakes in understanding their profession 
will affect teacher function movement. The existence of human resources in Islamic education institutions directly will influent the quality of teacher performance to make discipline. Based on an issue, the researcher interest to study with the title human resources on increasing teacher performance in Islamic educational institutions.

\section{METHOD}

This study with the title is "human resources on increasing teacher performant in Islamic education Institutions" means all human resources at Pondok Banyumas on increase teacher performance. Human resources at Pondok Banyumas includes chief of pondok, ustad/ustazah, and committee pondok Banyumas Jawa Tengah.

Suitable with the problem that focuses on this study "human resources on increasing teacher performant in Islamic education institution" the approach used in this study is qualitative. Qualitative is a research paradigm to describe an issue, human behavior, or situation in a certain place with detail and depth on narration. The kind of research is descriptive. This research, namely field research is a data collecting method process suitable with the target or research problem such as detailed information and symptom in the field. The research procedure is a research procedure that produces descriptive data orally and written of human behavior can observe. The qualitative approach is drawing the systematic fact and characteristic object and subject studied with an objective.

To analyze the collected data, the authors followed four steps of data analysis proposed by (Miles and Huberman, 1994) coding, categorization, memo ring, and developing propositions. Data collecting techniques in this study are in-depth interviews how is increasing teacher performance through human resources, participant observation about increasing teacher performance, and documentation about increasing teacher performance to get high credibility. This study is done by the researcher with direct research in the field at Pondok Banyumas Jawa Tengah begin February 10 th,- Jun 12th 2021.

Data analysis on qualitative research before, during, and after field, data analysis begins to display the problem while in the field until the research report (Sugiyono, 2009). Data analysis process is beginning analysis from all the data from many sources with interview, observation and documentation. The activity data analysis did by the researcher with interactive and continuous until the finish. The activity of data analysis done by the researcher includes data reduction, display, and conclusion (Sugiyono, 2009).

\section{RESULT and DISCUSSION}

On the increasing quality of an educational institution is need good management especially human resources and teacher performance. This study did at Pondok Pesantren Banyumas Jawa Tengah, with the focus of study on human resources and sub-focus is increasing teacher performance.

The data collecting method and information is used descriptive qualitative, with data collecting method is an interview, observation, and documentation. The technique used can delve deeply related to human resources includes recruitment, selection, appraisal, and teacher performance development at Pondok Pesantren Banyumas Jawa Tengah.

The implementation of human resources management at Pondok Pesantren Banyumas Jawa Tengah includes many activities such as human resources planning, recruitment and selection, placement or orientation, teacher performant assessment, training, and carrier development, compensation and allowance, and dismissal. According to the chief of Pesantren Banyumas Jawa Tengah, the human resources process needed placement of human resources, training, and development, assessment, and compensation. The activity is planning, recruitment, and selection to placement at Pondok Pesantren.

\section{Human resources placement}

Human resources placement at Pondok pesantren related with class parent distribution did at the beginning of learning the years, meeting principle and teachers. Class parent 
movement, from low-class level to high-class level or vice versa, Placement is also attention on teacher ability. Suitable with Chief Pondok Pesantren Banyumas statement, placement customized with teacher ability and suitable with teacher expectation:

Teacher placement is suitable with their ability and expected and discusses at the beginning of the learning years. Curriculum direct to Kyai. He wants a perfect curriculum. Now he takes cooperating with Middle East schools, such as senior high school Al Azar. Before the student goes to al Azar did training in Mahat Ali, he benchmarks to Al Azar. To government policy sometimes made self, such as school holiday. Every month teachers and students recite Rohibil Hajat to care Ukhuwah. He hopes this school can compete with private schools and can produce Muslim Islamic figures (Interview, February $18^{\text {th }}, 202110.00$ AM).

Based on observation, teacher placement is suitable with their ability and expected and discusses at the beginning of the learning years. Similarity with a teacher statement at Pondok Pesantren Banyumas said that the placement of class parent always discussion in meeting:

Placement class parent is a principal proposal which decided with a meeting, and the result of the decision implemented if there is a teacher objection can submit the request with the best reason, actually, the teacher must be ready to put at various classes (Interview, February 19th 20219.30 AM).

Based on interview and observation at Pondok Pesantren Banyumas present that teacher placement is done with meeting to decided class parent with consider each teacher ability and attention condition of individual who have patient on face student problem especially new student at Pondok Pesantren Banyumas.

\section{Training and development}

Training and development of human resources are very important for the teachers because development is life sector especially knowledge and technology is always developing, so the teacher must increasing their competency. The training and development program at Pondok Pesantren Banyumas is done based on the government program. Following government programs can increasing teacher performance and can be more professional. It is explained chief of Pondok Pesantren Banyumas:

For education qualification, Alhamdulillah they have bachelor except two peoples, while for the teacher training based on a government program. If there is a training, A principal delegates a teacher to following the training suitable with their subject. Implemented KKG activity local level, but still not implemented well (Interview, February 17th,2021 11.45 AM).

The result of the interview is present of organizing and implementation training program, the program made by government and participate from Pondok Pesantren Banyumas in those programs, delegate the teacher to follow the program as a participant. This activity is arranged to increasing teacher quality in teaching includes teaching material or method and administration of Pondok Pesantren.

The result of the interview is supported with observation done by the researcher to teach the teacher with qualification bachelor. There is a teacher who gets an Honoris cause degree from the Middle East. There is a KKG forum as teacher media to increasing the ability to implement the teaching and learning process. KKD is as media to sharing teacher outlook, knowledge, and information about the development of knowledge and teaching method, and sharing ideas and problems faced by the teacher to get a solution. However, the implementation of the KKG program did not run maximally and was suitable for the schedule planned.

\section{Performance assessment}

Performance assessment at Pondok Pesantren Banyumas did formal and informal on personal achievement. Informal assessment is done by the chief of Pondok continuously subjectively, vice versa, the Chief of Pondok Pesantren can use the formal technique on teacher performant assessment, and this assessment more objectively. Teacher performance at Pondok Pesantren Banyumas is a systematic assessment of performance and teacher potential for selfdevelopment. The teacher assessment object at Pondok Pesantren Banyumas is to increasing quality and evaluate the missing implementation stages, performance object assessment is 
poured on performant standards includes discipline, performant sustainability, motivation, loyal, skill, ability, general skill, etc.

According to the chief of Pondok Pesantren Banyumas said that teacher performance assessment namely, PKG which have elements of assessment are loyalty, work performance, responsibility, obedience, honesty, cooperation, initiative, discipline, and skills:

Teacher performance assessment has civil status using DP 3 or PKG for new and the element of assessment target is loyalty, work performance, responsibility, obedience, honesty, cooperation, initiative, discipline, and skills. Besides this assessment, there is learning administration assessment and class supervision in every semester and as assessment of how teachers teach and complete learning administration such as attendance list, syllabus, annual program and semester program, mapping, lesson plan, and student assessment (Interview, February 22 $2^{\text {th }}, 2021$ 10.00 AM).

The result of the interview above is presented not only elements of assessment but also teaching and learning process related mastery of the material, method and learning strategy used, discipline on teaching. The result of the interview support by observation is done by the researcher, there is discipline, on time during coming to the class and complete the administration.

Discipline must have by the teacher (ustadz) in an Islamic educational institution. It's suitable with Ustad Andre opinion (vice principle curriculum:

Kyai often control to Pondok, to junior high school, he have high discipline. He has incredible policy, he put one suitable with capacity and their subject. For management, he ask consideration from Abah Dayono who take a position under foundation in institution structure (Interview, February $23^{\text {th }}, 202108.45 \mathrm{AM}$ ).

Related with discipline, Abah Anam as a model (Kyai) gives example about it:

Abah Anam is a Kyai cadre by his father to continue his father's struggle, who has high discipline because he has military education. Gus Anam just graduates from junior high school, and in Pesantren. Gus Anam is a smart one, he can remember Alfiyah before going to Pesantren (Interview, February $20^{\text {th }}, 202109.00 \mathrm{AM}$ ).

Based on the explanation above, the teacher at Pondok Pesantren Banyumas Jawa Tengah is a teacher who has high discipline, because of a model from a military education. Suitable with the observation of the researcher that Abah Anam (Kyai) is a figure and model with high discipline. Discipline in this Islamic education institution can answer the challenges today, so the Pesantren is not the last choice but becomes an agent of change especially Akhlak. Pesantren as the front line to educate Akhlak (Pesantren base school), Andalusia (as modern Salafi) is combined education type Pesantren formal and non-formal, from the benchmark in the Middle East.

Coaching on increasing teacher performance is done through periodic supervision. The principal and supervisor did supervision with administration audits and class visiting. A teacher Pondok Pesantren Banyumas said that the teacher performance assessment did by the principal that the assessment target suitable with DP 3 or PKG includes: discipline, loyalty, work performance, responsibility, obedience, honesty, and cooperation, etc. Also is class supervision and learning administration audit (Interview, February $23^{\text {th }}, 202111.15$ AM).

Assessment is a benchmark of improving the performance and teacher performant development, as a material of motivating each individual after measure their performance, as a basic consideration to guide the process and personnel development on improving their performance, and as a determinant for promotion. Performance assessment is as consideration to decided low or high incentive.

\section{Compensation}

Compensation or incentive at Pondok Pesantren Banyumas gives a reward, and thanks to the teacher minimum related their task finished, give welfare on financial suitable with their tasks. Chief of Pondok Pesantren Banyumas said that:

Compensation or incentive is given a reward and says thanks, the compensation is material. Salary given to the teacher suitable with the workload, the task, and the activity implemented which take from BOS fund and GRATIS fund especially for non-permanent teacher, while the 
civil, intensive give suitable extra hour and the activity add to increasing performance (Interview, February $22^{\text {th }}, 202110.15$ AM).

Support by committee Pondok Pesantren Banyumas said that:

Compensation is given by Pondok Pesantren Banyumas suitable with my expected as an extraordinary teacher and suitable with my task and responsibility, for civil suitable with additional task and activity did as motivation to increase our performance (Interview, February $\left.23^{\text {th }}, 202109.00 \mathrm{AM}\right)$.

Based on the interview result present that, compensation given a reward and salary based on their task and suitable with the activity did. Compensation appropriate with teacher expectation to motivate performance batter and professional. Suitable with researcher observation, there is compensation at Pondok Pesantren Banyumas done with giving reward and salary based on their workload (Observation, February 19th,2021 10.00 AM). The salary given to the teacher includes allowance or incentive in each activity did by the teacher besides their salary. Special for non-civil usually give three months take from BOS grant and incentive from aid society.

Observation results related to teacher performance, many problems at Pondok Pesantren Banyumas Jawa Tengah are: first, miss quality performance because many teachers are not present each month. Second, low-quality performant causes many teachers is not attention to accuracy and neatness in their task, third low cooperation between teachers. Fourth, low responsibility percentage, there is a teacher confess the result and their mistake on decision making. The fifth, low initiative when spare time situation, the teacher did not have other tasks, they just play the phone (Observation, February 16 ${ }^{\text {th }}, 2021$ 10.00 AM).

Related to that phenomenon, many problems are rising at Pondok Pesantren Banyumas Jawa Tengah caused by an inner factor, limited their knowledge, learning facility or interest to increasing their competency, so influence in low teacher performance on student service. If those problems are ignoring, the success of improving education quality will be constrained. Many teachers less participate in increasing performance activity as an effort in increasing human resources.

Teacher performance at Pondok Pesantren Banyumas Jawa Tengah takes categorize as good when teaching and learning process in the class or outside of the class, when teaching and learning process is suitable with curriculum and guidelines (syllabus and lesson plan), although there is a teacher not bring learning tool, with the reason he has to remember the material. According to Chief Pondok Pesantren Banyumas said that:

Teacher performance at Pondok Pesantren Banyumas Jawa Tengah belongs to categorize good because all the tasks implemented well and full responsibility. They adapted from the curriculum, syllabus, and lesson plan as guidelines. Extra-curricular did outside teaching and learning processes such as Drum Band, Pramuka, art and sport, and religious every week (Interview, February $25^{\text {th }}, 202110.00 \mathrm{AM}$ ).

If teacher performance is not suitable with institution expectations, the teacher will get a warning and guidance through MGMP. According to the committee, Pondok Pesantren Banyumas explain that:

Through giving guidance and coaching, the principal makes MGMP (Musyawarah Guru Mata Pelajaran) or teacher discussion on their subject. MGMP can use to arrange and evaluate student learning development. This evaluation did a periodical, and the result uses to arrange the next lesson plan. The teacher must be able to individual duty to improve themselves in teaching and learning process (Interview, February $25^{\text {th }}, 2021$ 11.25 AM).

Based on researcher observation, teacher performance is not suitable with institution expectation the teacher will give warning and guidance. The purpose of warning and guidance is to change the teacher performance to be better and can increase (Observation, February $\left.16^{\text {th }}, 202111.00 \mathrm{AM}\right)$.

Continuous guidance will become professional. The professional teacher is the teacher can manage themselves to implementation their tasks. A Professional teacher is not separable from their skill and their motivation. A teacher will work professionally, if they have high skills, 
determination, motivation, commitment, work hard, smart, complete work, Ikhlas, and satisfaction, it will be set by Pondok Pesantren Banyumas Jawa Tengah.

Teachers play an important role to communicate and help students build their way, hence student integrity can build not only intellectuality but also social and spiritual. The conclusions, the strategy used at Pondok Pesantren Banyumas Jawa Tengah to increase teacher performance strategy are discipline, training, workshop, reward, and monitoring.

\section{RESULT and DISCUSSION}

Interpret data findings based on data findings. The discussion classifies into three mains are human resources drawing at Pondok Pesantren Banyumas, teacher performance, and increasing teacher performance. Three main elaborate on this discussion:

\section{The drawing of human resources}

Based on the data, the researcher finding the number of teachers at Pondok Pesantren Banyumas is already fulfilled. Approximately, the religious teachers have education qualification bachelor, many teachers learn in the Middle East and get Honoris cause.

As a result of this study, many teachers have bachelor's qualifications. bachelor qualification is a requirement for teacher recruitment. A teacher is a determining factor in educational success, especially in increasing human resources resulted from education. Therefore, in educational institutions, the teacher plays an important role, strategic and key to success. The teacher will decide education institution progress and backward. Therefore, to become an educational institution quality, the teacher and staff must have education qualification, scientific capacity, competency, high dedication, and professionalism. Teachers and staff are expected the teaching and learning process to run well and produce output with quality.

Increasing professional competency, the teacher must be continuously improvement and take advantage of the momentum. The momentums are continued study, following the training and workshop, and not stagnant to develop their competency to become a professional teacher. As a professional teacher, A teacher must have many things, such as commitment, implementation of teaching and learning process, mastery of the material and can teach the student, student assessment through evaluation technique, the teacher can systematic thought, learning from experience, and teacher as part of the society and part of professional environment.

Human resources play important in education are: manage, set, and take advantage of the teacher and staff to get the function of productivity. Human resources take place as an important element of an organization. The human resources aspect will produce high institution performance without rule out another aspect. Human resources planning is an important part must run of the organization. Human resources planning is the certain stage take by management to assurance the organization about available staff to manage human resources, and a contributor to strategic planning, strategic planning, is not only helping the organization on human resources decide but also decide human resources goal. The effect will give an advantage for an organization to decrease uncertainly.

The basics of human resources have a high influence and as the mains key to increasing education quality. Means all the human resources in an institution, human resources are resources that have thought, fill, desire, ability, skill, knowledge, taste, and intention. Human resources potential is influenced by achieving organization goals, although technological sophistication development. According to Faustino explain, there are many problems related to human resources in an organization includes employing teachers and staff are not being suitable with their skills, injustice salary, promos, and staff practice, less training, and teacher development (Gomes, 2011).

The existence of human resources in an educational institution has increased to become a strategic role nowadays to support the future. All aspects of planning, organizing, delegating, leadership, and controlling need teacher direction which has the function of human resources to 
increasing education quality (Bedjo Sujanto, 2007). The importance of existing human resources on improving education quality is human resources need to set and manage to get results maximally. Manage the human resources by an effective and efficient manager will achieve education goal optimally to increasing education quality in Indonesia, human resources quality, Indonesia government, and private institutions together to achieve educational quality.

The explanation above, education quality is coveted by society, especially for learners. Teacher quality will create quality students. The effort to increasing teacher quality did selectively and to achieve education goals maximally. The teacher is a human resource who plays an important role to decides education success, teacher as a subject of education in the institution. Human resource is an important factor which as part of school management and teacher as a central factor. The teacher must be a professional, success or not a teaching and learning process depend on the teacher and produce quality output.

\section{Teacher performance}

A pleasant work environment is keys support for the teacher and staff to produce performance optimally. The work environment is decided by understanding the goal where support teachers to cooperate to achieve the goal. School rule enforcement will produce a conducive situation so the teacher can work with pleasure (Kemendiknas, 2002).

Teacher performance is not only seen from teaching and learning activity in the class, but also educate aspect, training, guidance, and direction can see extracurricular in every week. Teacher performance at Pondok Pesantren Banyumas Jawa Tengah is optimal yet. Many teachers cannot do their tasks on time. Another problem at Pondok Pesantren Banyumas Jawa Tengah is less responsibility for their work that can influence quality. Besides, many teachers have been absent and late when they are teaching and did not bring the media and administration of teaching, he said that he remembers about the material.

The lesson plan and syllabus is an administration that must fulfill by the teacher on learning activities. Lesson plan and syllabus is the main requirement as learning guideline. Lesson plan and syllabus available is a part of teacher performance which can observe from their skill on implementation their task and their responsibility. Their performance is reflected work style which can increase education quality batter. The teacher will work professionally if they have high ability and seriousness sincerity to do the best task, vice versa, they will not work professionally, if just fulfill a requirement. Although they have high qualifications, they will not work professionally, if they did not have personality and high dedication.

The teachers have good performance; certainly have a high commitment in their personality, means reflected from personality and high dedication. The teacher commitment level is in a continuum line from low to high. Teacher commitment low is less attention to their student, as well as time and their energy just to increasing education quality, vice versa a teacher has a high commitment, also has a high attention to their work with much time. The abstraction level means teacher skill level on learning management, problems clarification, and decide alternative solve the problems (Nurdin and Bakar, 2013).

The performance standard is needs formulated as guidelines to compare between achievement and expectation, performance quality as an activity which implemented suitable with expectation or achievement the goal, effectively and efficiently. To achieve the goal, often teacher performant faced much threat, and the end produces less effective performance, another word performance standard can as reference or benchmark on their work responsibility.

\section{Human resources development on increasing teacher performance}

In the activity realm, the implementation of human resources on education management must orientation on effectivity education aspect in development. The cause is an educational institution that upholds human resources quality and benefits for society, nation, and state. The finding of study, human resources implementation well will give a positive influence on increasing teacher performance. The obstacle on implementation human resources on increasing teacher performance at Pondok Pesantren Banyumas especially on implementation 
task in the class, there is a teacher on implementation learning process not preparing what they need such as preparing a lesson plan and media.

See this condition, the principal must arrange school plan in many levels of planning and institution development suitable with institution need on resources empowerment optimally, manage teacher and staff on human resources empowerment optimally, manage student on student acceptance, student placement, and student development capacity, manage curriculum development, and manage the activity suitable with the direction of national education goal. Planning program arrangement and school activity will be implemented a principal discuss with the teachers formally with meeting at the beginning of the year's learning and non-formal meeting.

The result analysis many obstacles above did the researcher is teacher personal awareness and school control system. To solve the obstacles, the principal must creatively create a system and mechanism control on learning activity done by a teacher. However, the key of the problem takes place on teacher personal awareness on implementation their task in the class. Although, mechanism control has been designed. However, it is not supported by teacher professional awareness, so the increasing teacher performance will not build like expected. Increasing teacher performance can be done through human resources development (Sjafri Mangkuprawira, 2011) includes the principal gives assign to following the training, workshop, internship and scientific work.

Human resources in Islamic educational institutions must be managed well, such as curriculum and learning program, teacher and staff, student affairs, financial, infrastructure, public relations, and human resources management service development (Abdurahmat Fathoni, 2013) includes first, human resources management in curriculum and learning programs includes planning activity and national curriculum development which, did by the ministry of education and culture. Second, human resources management in teachers and staff is determinant by leadership on manage teachers and staff in their institution. Third, Human resources management manage by student affairs, student affair aims to manage many student activities running well and achieve the goal. To achieve the goal, student affairs must have three main tasks student admission, learning activity development, guidance, and coaching discipline. Fourth, human resources management in financial and empowerment, organization institution, finance, and financing is decided potential and inseparable in human resources study. In educational institution, the finance component is the production component which is the determination of implementation of the teaching and learning process. In other words, each activity is done need cost, realize or not. The financial component is needed to manage well, in other that funds can use optimally to support educational achievement goals. Fifth, human resources management in education infrastructure, good infrastructure can create beautifully, and clean to creating condition pleasant for teacher or student when they in the school. Sixth, human resources management in public relations, a principal is a key for success to create a relationship between school and environment society effectively because what the public need focus on student. A principal must guide and increasing relationships with society to achieve effective and efficient schools.and the last human resources management in special service, include the library, health, and security. An educational institution will sustainable and develop adaptation from environment support by the human. To achieve organization goal, the organization make a job analysis which must do to give description about task, responsibility, task characteristic, and job requirement to did well.

In curriculum development and learning is suggested to be directly involved with a student in the teaching and learning process. Related to teacher task achieve optimally seen the result of student assessment with high score. The teacher's performance is reflected in daily activity tasks and functions on the learning process, in or outside the class as a teacher trainer. They did plan, implement, and evaluate of the learning process with intensity based on moral attitude and professional teacher.

Teacher performance is decided by discipline in an internal institution. Many problems are present such as following specified time, many teachers teaching less the time of learning 
schedule when teaching in the class. Many teachers cannot finish their learning administration on time. And following etic code which can be seen from their attitude and behavior on their duty such as many teachers leave their job to personal interest without permission.

\section{DISCUSSION}

Based on the data analysis, the researcher takes a conclusion are:

\section{Human resources drawing at Pondok Pesantren Banyumas}

The teacher aspect of quality and quantity especially, education qualification level is fulfilled. The number of the teacher at Pondok Pesantren Banyumas sudah is fulfilled. To religious teachers have bachelor education qualifications, many teachers learning in the Middle East. Human resources at Pondok Pesantren Banyumas Jawa Tengah have managed well-seen planning, recruitment, selection, placement/ orientation, teacher performance assessment, training and carrier development, compensation and allowance, teacher dismissal.

\section{Techer performance}

Teacher performance at Pondok Pesantren Banyumas Jawa Tengah is still not optimal because many teachers cannot finish their tasks on time. Another problem at Pondok Pesantren Banyumas Jawa Tengah is less responsibility for their task as a teacher who influent their quality. Many teachers are absent and late in the teaching and learning process, there is a teacher not bring teaching administration and media with the reason they remember about the material, although many teachers have high discipline.

\section{Human resources development on teacher performance}

Human resources management implementation implemented well will positively affect increasing teacher performance. There are many obstacles to human resources implementation to improve teacher performance at Pondok Pesantren Banyumas, especially on-task implementation. Many teachers do without preparing the learning administration (lesson plan and media) like a professional teacher. Increasing teacher performant will affect human capital (Anggraeni, K. 2021)

The implications of this study are first: for the principal, this study can as information and reference to review human resources management activity at Pondok Pesantren Banyumas on increasing teacher performance. It is important not only as a production factor but also as an asset, so it must get special attention. Therefore, the teacher must be seen as a complex human who has a kind of need. Second, teachers must increase their ability and their professional through many independent efforts did. Third, for educational institution management, the implementation of human resources management in many schools needs evaluating intensively to teacher's potential advantages and weaknesses in each school. Fourth, For other researchers, this study can follow up with other models. Many objects of and using many parameters and indicators to reveal the reality.

The conclusion of this study is based on field, many dominant factors that influence teacher performance are competency and discipline as dominant factors. According to chief Pondok Pesantren Banyumas Jawa Tengah, many teachers can adapt yet with their performance when they are teaching, especially new teachers. While discipline, A principle said that discipline level optimal yet. Many teachers are absent without clear reasons, this condition will not achieve the goal. Implementation of human resources management did well and given an effect on increasing teacher performance, It has proven with planning, recruitment, teacher selection, placement process or orientation, teacher performance assessment, training, carrier development, compensation and allowance, teacher dismissal given an effect on increasing teacher performance. 


\section{ACKNOWLEDGMENT}

Thank to informant at Pondok Pesantren Banyumas who help us in this research and also thanks to our team always cooperation to finishing this research. May our study give advantage for Pondok Pesantren banyumas to develop their institution and for future research.

\section{REFERENCES}

Anggraeni, K. (2021). Human capital management system a multisite study At State Universities in Malang: State Islamic University of Maulana Malik Ibrahim Malang, State University of Malang and Brawijaya University (Doctoral dissertation, Universitas Islam Negeri Maulana Malik Ibrahim).

Anggraeni, K. (n.d.). The Role of open system and human capital in education. 11.

Bafadal, Ibrahim, Peningkatan Profesionalisme Guru dalam Kerangka Manajemen Peningkatan Mutu Berbasis Sekolah, Jakarta: Bumi Aksara, 2012.

Fathoni, Abdurahmat, Manajemen Sumber Daya Manusia, Jakarta: PT Rineka Cipta, 2013.

Fattah, Nanang, Landasan Manajemen Pendidikan, Bandung: Remaja Rosdakarya, 2015.

Gomes, Faustino Cardoso, Manajemen Sumber Daya Manusia, Yogyakarta: Andi Offset, 2012.

Hasibuan, Malayu S.P. Manajemen Sumber Daya Manusia, Jakarta: Bumi Aksara, 2012.

Herman, Sofyandi Manajemen Sumber Daya Manusia, Yogyakarta: Graha Ilmu, 2014.

Kementrian Pendidikan Nasional, edisi revisi Jakarta: Kemendiknas, 2013.

Mangkuprawira, Sjafri, Manajemen Sumber Daya Manusia Strategik, Bogor: Ghalia Indonesia, 2011.

Marsana dan Handayani, Pengaruh Kompetensi dan Motivasi Kerja, Bandung: Refika Aditama, 2012.

Matthew B Miles and Michael Huberman, Qualitative data Analysis second edition (UK: Sage publication 1994)

Muhaimin, Strategi Belajar Mengajar: Penerapannya dalam Pembelajaran Pendidikan Agama, Surabaya: Citra Media, 2016.

Nurdin, Diding dan Abu Bakar, Manajemen Sumber Daya Pendidikan, Bandung: Transito, 2013.

Nurdin, Syafruddin, Guru Profesional dan Implementasi Kurikulum, Jakarta: Ciputat Pers, 2013.

Rosyadi, Koiron, Pendidikan Profetik, Yogyakarta: Pustaka Pelajar Offset, 2014.

Siagian, Manajemen Sumber Daya Manusia, Jakarta: Bumi Aksara, 2013.

Sugiyono, Metode Penelitian Kuantitatif Kualitatif dan R \& D, Bandung: Alfabeta, 2015.

Sujanto, Bedjo, Manajemen Pendidikan Berbasis Sekolah, Jakarta: Sagung Seto, 2007.

Sutrisno, Manajemen Sumber Daya Manusia, Jakarta: Kencana, 2011.

Usman, Moh. Uzer, Menjadi Guru Profesional, Bandung: Remaja Rosda Karya, 2012.

Yuliani, Tutik, Faktor-faktor yang Mempengaruhi Kinerja Guru, Balikpapan: Prosiding Seminar Nasional Pendidikan, 2018. 